\title{
SIKAP MAHASISWA TINGKAT AKHIR SELAMA MENJALANI PERKULIAHAN DI JURUSAN BIMBINGAN DAN KONSELING UNIVERSITAS NEGERI JAKARTA
}

\author{
SitaGiusvina Bratanagara ${ }^{1}$ \\ Dra Wirda Hanim, M.Psi. ${ }^{2}$ \\ Sjenny A. Indrawaty, Ed. D. ${ }^{3}$
}

\begin{abstract}
Abstrak
Penelitian ini bertujuan untuk mengetahui sikap mahasiswa tingkat akhir selama menjalani perkuliahan di jurusan Bimbingan dan Konseling Universitas Negeri Jakarta. Subjek pada penelitian ini adalah 2 orang mahasiswa kelas Reguler 2007 dan Non Reguler 2008. Responden diambil berdasarkan hasil studi pendahuluan dan observasi secara insidental untuk mengetahui sikap mahasiswa tingkat akhir selama menjalani perkuliahan. Pengumpulan data dilakukan melalui wawancara, observasi dan studi dokumentasi. Wawancara yang dilakukan secara terstruktur terhadap subjek atau kasus, teman sebaya, dosen yang mengenal subjek, dengan mengacu pada teori sikap oleh Mar'at. Data hasil penelitian dianalisis dengan pendekatan kualitatif dengan metode studi kasus, penyajian data menggunakan narasi. Pemeriksaan keabsahan data dilakukan dengan triangulasi sumber data. Hasil penelitian keseluruhan menunjukan subjek pertama awalnya memilih jurusan Bimbingan dan Konseling karena merasa kesulitan serta terancam dropout dari jurusan sebelumnya yaitu Bahasa Perancis. Sedangkan subjek kedua memilih jurusan Bimbingan dan Konseling awalnya karena tertarik menjadi guru, namun mengalami penurunan minat sejak subjek merasa pelayanan, perkuliahan dan sistem penilaian di Jurusan BK kurang memuaskan, yang berakibat nilai mata kuliah yang subjek peroleh pun kurang memuaskan. Untuk beberapa mata kuliah, subjek terpaksa harus mengulang sehingga subjek tidak bersemangat kuliah di BK. Saat mengikuti program pengalaman lapangan (PPL), subjek melihat guru pamong tidak memiliki gambaran sikap dan kepribadian yang ideal sebagai guru Bimbingan dan Konseling. Hal ini semakin menurunkan keyakinan subjek untuk menjadi guru Bimbingan dan Konseling, dan ingin berkarier di luar Bimbingan dan Konseling. Implikasi penelitian ini adalah 2 orang mahasiswa jurusan Bimbingan dan Konseling yang bermasalah, kurang mampu mengatasi permasalahan selama perkuliahan, serta kurang memiliki gambaran sikap yang baik selama perkuliahan.
\end{abstract}

Kata Kunci: Bimbingan dan Konseling, sikap, mahasiswa

\footnotetext{
Mahasiswa Jurusan Bimbingan dan Konseling FIP UNJ, sitabratanagara@gmail.com Dosen Bimbingan dan Konseling FIP UNJ,

3 Dosen Bimbingan dan Konseling FIP UNJ,
} 


\section{Pendahuluan}

Remaja (usia 18-22 tahun) yang belajar di perguruan tinggi menghabiskan waktu di luar keluarga individu menjalani salah satu perannya sebagai mahasiswa.Remaja yang telah memutuskan untuk melanjutkan pendidikan pada jenjang strata 1 (S1),yaitu mereka yang merancang masadepannya dengan merealisasikan dalam bentuk pemilihan fakultas serta jurusan yang sesuai dengan minatnya. Calon mahasiswa yang ingin memasuki fakultas dan jurusan yang mereka pilih mengikuti serangkaian tes.

Kenyataannya berbeda dengan calon mahasiswa yang memilihjurusanmaupun memutuskan untukmenempuhpendidikanjenjang strata satudengan motif sebagai ajang pemenuhan permintaan dari orangtua, sehingga anak hanya mengikuti keinginan orangtuanya, dengan jurusan yang dipilih pun sesuai dengan keinginan orangtuanya. Masuk kuliah karena sudah "tercebur" ke dalamnya dan selain itu jurusan yang dipilih tidak sesuai dengan minat. Aktifitas perkuliahan yang tidak sesuai dengan bakat dan minat mahasiswa sedikit banyaknya mempengaruhi mahasiswa selama menempuh pendidikan. Setelah dinyatakan bahwa dirinya diterima di universitas pada jurusan dan program studi yang akan dijalani selama kurang lebih 4 tahun ke depan membuat mereka harus belajar melaluisemuahal yang berkaitandenganjurusan yang telahdipilihmelalui proses perkuliahan.

Ada 2 mahasiswa pada jurusan Bimbingan dan Konseling diantaranya yang belum benar-benarmemahami hal yang harus ditingkatkan dalam mencapai kematangan sikap dan kepribadian mereka. Beberapa mahasiswa belum sepenuhnya mampu mengelola emosinya dengan baik, cenderung meledakledak dalam menyikapi permasalahan yang ada. Kesadaran bahwa mereka adalah calon Guru Bimbingan dan Konseling atau konselor yang akhirnya akan menjadi model dihadapan para siswanya nampaknya kesadaran ini belum sepenuhnya tertanam dalam diri mereka. Mahasiswa cenderungkurangpedulidalam berbicara, bersikap dan bertindak serta menanggapi sesuatu hal. Berbagai hal lain dalam sikap dan kepribadian yang memprihatinkan, terjadi selama menjalani perkuliahan.

Rumusan masalah "bagaimana sikap mahasiswa tingkat akhir selama menjalani perkuliahan di juru- san Bimbingan dan Konseling Universitas Negeri Jakarta."?. Tujuan penelitian ini adalah untuk mengungkap berbagai fakta tentang sikap mahasiswa tingkat akhir selama menjalani perkuliahan di jurusan Bimbingan dan Konseling Universitas Negeri Jakarta.

\section{Kajian Teori \\ Sikap}

Mar'at, menjelaskan tiga komponen sikap yang saling menunjang satu sama lain. Pertama, komponen kognisi. Komponen kognisi mencakup penerimaan informasi yang ditangkap oleh panca indera, yang kemudian diproses dan dipersepsikan, dibandingkan dengan data/informasi yang telah dimiliki, diklasifikasikan, lalu disimpan dalam ingatan dan digunakan dalam merespon rangsangan.

Mar'at menambahkan bahwa komponen pertama kognisi berisi pemikiran, ide-ide, maupun pendapat yang berkenaan denganobjek sikap. Pemikiran tersebut meliputi hal-hal yang diketahui individu mengenai objek sikap, dapat berupa keyakinan atau tanggapan, kesan,atribusi, dan penilaian terhadap objek sikap.

Kedua, komponen afeksi berhubungan dengan perasaan atau emosiindividu yang berupa senang atau tidak senang terhadap objek sikap.

Ketiga, komponen konasi yang merujuk kepada kecenderungantindakan atau respon individu terhadap objek sikap yang berasal dari masa lalu. Respon yang dimaksud dapat berupa tindakan yang dapat diamati dan dapat berupa niat atau intensi untuk melakukan perbuatan tertentu sehubungan dengan objek sikap .

Berbeda dengan komponen afeksi dan kognisi, perilaku sebagai komponen sikap yang dapat diamati seringkali menjadi perdebatan para ahli terkait konsistensinya dengan sikap individu.

\section{Metode Penelitian}

Penelitian ini dilaksanakan di Jurusan Bimbingan dan Konseling Universitas Negeri Jakarta dengan dua subjek penelitian yaitu mahasiswa tingkat akhir kelas Reguler 2007 dan mahasiswa tingkat akhir kelas Non Reguler 2008. Jurusan Bimbingan dan Konseling berada di Fakultas Ilmu Pendidikan 
Universitas Negeri Jakarta memiliki tujuan akhir menghasilkan Guru Bimbingan dan Konseling.

Waktu pelaksanaan penelitian ini dilakukan pada bulan Oktober 2013 sampai dengan Maret 2014. Metode yang digunakan dalam penelitian ini adalah pendekatan penelitian kualitatif dengan metode case study (studi kasus).

Alasan peneliti memilih metode studi kasus karena fokus penelitian terletak pada fenomena masa kini di dalam konteks kehidupan nyata dengan memanfaatkan multisumber, pada penelitian studi kasus, peneliti dapat meneliti individu secara single case study atau multi case study. Jadi, pada penelitian ini peneliti berusaha menyusun, menggambarkan, dan menganalisa sikap mahasiswa tingkat akhir jurusan Bimbingan dan Konseling terhadap kepribadian calon konselor dengan memfokuskan penelitian pada dua subjek penelitian.

Kisi-kisi wawancara yang digunakan dari teori sikap yang dikembangkan oleh Mar,at. Sebelum wawancara dilaksanakan, dilakukan uji coba terlebih dahulu terhadap 2 orang mahasiswa tingkat akhir secara acakuntuk mengukur tingkat validitas kisi-kisi wawancara.

Kisi-kisi Wawancara

\begin{tabular}{|c|c|c|}
\hline VARIABEL & \begin{tabular}{|c|}
$\begin{array}{c}\text { Indikator } \\
\text { Komponen } \\
\text { Sikap }\end{array}$ \\
\end{tabular} & Deskriptor \\
\hline \multirow{6}{*}{$\begin{array}{l}\text { Sikap Mahasiswa } \\
\text { Tingkat Akhir } \\
\text { selama Menjalani } \\
\text { Perkuliahan di } \\
\text { Jurusan Bimbingan } \\
\text { dan Konseling } \\
\text { Universitas Negeri } \\
\text { Jakarta }\end{array}$} & \multirow{2}{*}{$\begin{array}{c}\text { Aspek } \\
\text { Kognitif }\end{array}$} & Belief (Kepercayaan, keyakinan) \\
\hline & & Ide \\
\hline & \multirow{2}{*}{$\begin{array}{l}\text { Aspek } \\
\text { Afektif }\end{array}$} & Kehidupan Emosi Seseorang \\
\hline & & $\begin{array}{l}\text { Dimensi positif, negatif, atau bahkan } \\
\text { ragu-ragu terhadap objek sikap }\end{array}$ \\
\hline & \multirow[t]{2}{*}{$\begin{array}{l}\text { Aspek } \\
\text { Konatif }\end{array}$} & $\begin{array}{l}\text { Penafsiran tingkah laku yang mungkin } \\
\text { menjadi indikator yang sempurna } \\
\text { atau bahkan yang tidak memadai }\end{array}$ \\
\hline & & Kecenderungan tingkah laku \\
\hline
\end{tabular}

\section{Hasil dan Pembahasan}

Responden penelitian ini sebanyak 2 orang lakilaki mahasiswa tingkat akhir kelas Reguler 2007 (A) dan kelas Non Reguler 2008 (H). Subjek pertama (A) merupakan mahasiswa tingkat akhir yang memiliki kemampuan kognitif yang baik, namun tidak memiliki keyakinan serta minat untuk menjadi konselor hal ini karena subjek motivasi subjek memilih kuliah di BK karena terancam dropout di jurusan Bahasa Perancis dan atas perkataan teman,subjek berpikir jurusan BK lebih mudah namun kenyataan pada proses perkuliahan tidak seperti yang sub- jek pikirkan sebelumnya, subjek kurang mengetahui mengenai visi dan misi BK secara detail selain output jurusan BK adalah menghasilkan guru BK, subjek merasa proses perkuliahan di BK sebagian sudah sesuai visi dan misi BK dengan acuan pada dosen tertentu, subjek tidak mengalami perubahan sikap dan kepribadian selama kuliah di BK, hal ini karena sesekali subjek masih menggunakan obat-obatan terlarang dan minum-minuman keras, harapan subjek selama kuliah di BK adalah hubungan dosen dan mahasiswa lebih sehat, dosen pun lebih profesional selama mengajar di BK UNJ, subjek ingin keluar dari BK dan subjek yakin bahwa dirinya akan sukses meskipun tidak lulus di BK.

Sementara pada subjek kedua $(\mathrm{H})$ merupakan mahasiswa tingkat akhir yang memiliki kemampuan kognitif yang cukup baik, namun subjek tidak memiliki keyakinan serta minat untuk menjadi konselor namun subjek tetap ingin mengaplikasikan ilmunya di luar ruang lingkup sekolah, sesungguhnya motivasi subjek memilih kuliah di BK awalnya karena faktor ekseternal dari pandangan orangtua subjek yang menginginkan subjek memilih bidang keahlian yang akan menjamin masa depan subjek, dan akhirnya subjek ingin menjadi guru BK, namun karena rolemodel di sekeliling subjek terutama saat subjek ppl tidak menggambarkan sosok guru BK yang ideal, maka minat dan keyakinan subjek untuk menjadi guru BK atau konselor sekolah semakin berkurang, selain itu subjek berpikir melihat kenyataan pada pro-ses perkuliahan tidak seperti yang subjek pikirkan sebelumnya, subjek merasa ada ketidakjelasan dalam sistem penilaian di jurusan BK, subjek kurang mengetahui mengenai visi dan misi BK secara detail namun subjek meyakini sejogjanya visi dan misi adalah sesuatu yang ideal dan subjek merasa proses perkuliahan belum sesuai dengan visi dan misi BK dan dikaitkan dengan sistem penilaian yang subjek yakini penting, subjek merasakan ada perubahan sikap dan kepribadian selama kuliah di BK meskipun sedikit, harapan subjek selama kuliah di BK adalah hubungan dosen dan mahasiswa lebih sehat, dosen pun lebih profesional selama mengajar di BK UNJ, subjek ingin keluar dari BK dan subjek yakin bahwa dirinya bisa sukses setelah selesai kuliah di BK, meskipun subjek yakin bisa sukses dan berkarier di luar bidang BK. 


\section{Kesimpulan dan Saran Kesimpulan}

Pada subjek ( A)belum menggambarkan kepribadian calon konselor dan tidak mengalami perubahan sikap serta kepribadian yang signifikan, tidak mempunyai keyakinan serta motivasi yang kuat untuk menjadi guru BK atau calon konselor.Sementara pada $\operatorname{subjek}(\mathrm{H})$ secara sikap belum sepenuhnya menggambarkan kepribadian calon konselor dan mengalami sedikit perubahan pada sikap dan kepribadiannya. Keyakinan subjek untuk menjadi guru BK atau calon konselor semakin menurun. Persamaan antara subjek pertama (A) dan subjek kedua $(\mathrm{H})$ kedua-nya tidak memiliki minat atau keyakinan untuk menjadi konselor, walaupun demikian perbedaan antara subjek pertama (A) dengan subjek kedua $(\mathrm{H})$ bahwa subjek pertama (A) merasa bahwa tidak akan selesai kuliah di BK namun subjek pertama (A) yakin bahwa dirinya akan tetap sukses meskipun tidak lulus di BK dan akhir-akhir ini subjek pertama (A) ragu untuk tetap bertahan di BK atau pindah jurusan dan kampus. Sementara pada subjek kedua $(\mathrm{H})$ dirinya ingin secepatnya lulus kuliah di BK dan bekerja meskipun subjek kedua $(\mathrm{H})$ akan berkarir di luar bidang BK namun subjek kedua $(\mathrm{H})$ akan mengaplikasikan ilmu ke-BK-annya.

\section{Saran}

Saran yang dapat diberikan berdasarkan hasil penelitian ini bagi pihak-pihak terkait, yaitu:

\section{Ketua Jurusan Bimbingan dan Konseling}

Kepada Ketua Jurusan dan dosen Bimbingan dan Konseling diharapkan dapat menjadi bahan referensi dan evaluasi, terutama dalam meningkatkan mutu pelayanan dan pembelajaran dalam merancang program perkuliahan, sistem penilaian.

\section{Dosen Bimbingan dan Konseling}

Kepada Dosen Bimbingan dan Konseling diharapkan dapat membangun hubungan yang hangat dengan mahasiswa, memberikan penilaian secara objektif, lebih profesional dalam me-ngajar, merencanakan model-model pembelajaran di dalam kelas dan guna meningkatkan mutu mahasiswa khususnya dalam mengembangkan sikap mahasiswa selama menjalani perkuliahan.

\section{Mahasiswa Bimbingan dan Konseling} Kepada mahasiswa Bimbingan dan Konseling diharapkan dapat memiliki tanggung jawab atas diri sendiri berkaitan dengan tugas dan tanggung jawab selama perkuliahan, mampu mengatasi permasalahan selama perkuliahan, mampu memiliki gambaran sikap dan kepribadian yang baik sebagai langkah preventif dan berguna dalam mengembangkan sikap untuk masa sekarang maupun masa yang akan datang.

\section{Daftar Pustaka}

Buku KontrakMata Kuliah dan Data Kemajuan Akademik Mahasiswa Jurusan BK FIP UNJ , (Jakarta : 2008)

Departemen Pendidikan Nasional. 1995. Kamus Besar Bahasa Indonesia. Jakarta: Balai Pustaka.

Inge Hutagalung, Pengembangan Kepribadian (Jakarta: PT Indeks, 2007)

Mar'at, Sikap Manusia Perubahan Serta Pengukurannya (Jakarta : Ghalia Indonesia, 1981),

Moleong, Lexy J. Metodologi Penelitian Kualitatif edisi revisi (Bandung: PT Remaja Rosdakarya,2005).

Rita Yulifah, Tri Johan Agus Yuwanto, Komunikasi dan Konseling dalam Kebidanan (Jakarta: Salemba Medika, 2009)

Robert Nyin, Studi Kasus dan Metode (Jakarta: Rajawali Pers 2012).

Saifuddin Azwar, Sikap Manusia Teori dan Pengukurannya (Yogyakarta: Pustaka Pelajar, 2005)

Santrock, John W., Adolescence: Perkembangan Remaja (Jakarta: Erlangga, 2003).

Sugiyono, Memahami penelitian kualitatif (Bandung: Alfabeta,2008). 